УДК $343.35(477)$

\title{
DIFFERENTIATION OF THE CRIMINAL RESPONSIBILITY FOR ABUSE OF AUTHORITY UNDER CRIMINAL CODE OF UKRAINE
}

\author{
M.-M. Yatsynina \\ Ivan Franko National University of Lviv, \\ Universytetska Str., 1, Lviv, Ukraine, 79000, \\ e-mail:martamsy@gmail.com
}

The article examines the problem of differentiation of criminal responsibility for abuse of authority. It examines the criteria for differentiation of criminal responsibility for abuse committed by officials following the amendments to the Criminal Code of Ukraine made in 2011 by the law № 3207-VI dated April 7, 2011. The article analyses the appropriateness of criminal responsibility differentiation in examined group of crimes bearing in mind the criteria selected by Ukrainian legislators. While analyzing the changes, the author considers provisions of the United Nations Convention against Corruption and employs the method of systematic interpretation of criminal code.

In this research the author concludes that the responsibility of the officials should be differentiated on the basis of the essence of functions they perform. Based on that, criminal responsibility for abuse of power, and criminal responsibility for abuse of office irrespectively of ownership forms of enterprise, institution, or organization should be established separately.

Keywords: abuse of authority, abuse of power, abuse of official status, abuse of office.

Numerous amendments to the Criminal Code of Ukraine [3], concerning crimes in the area of official activities and professional activities related to the provision of public services, establish a need in fundamental research in this area. Actually, these changes are mainly related to the differentiation of criminal responsibility for the group of crimes which are examined in the framework of this article.

Amendments to the Criminal Code of Ukraine, differentiating criminal responsibility for power abuse, create a necessity to analyze the feasibility of such differentiation, the criteria by which it is carried out, which in turn also establishes an urgency to analyze the penalties of rules which provide responsibility for service abuse.

Till 2011, the only general rule establishing criminal responsibility for official crimes was Art. 364 of the Criminal Code of Ukraine «Abuse of Power or of Official Status».

In 2011, Criminal Code of Ukraine was corroborated by Art. 364 «Abuse of authority by an official legal entity of private law, regardless of its legal form».

Thus, up to now legislator has established such responsibility for the abuse in office by officials of public and private sector:

\begin{tabular}{|c|l|l|}
\hline $\begin{array}{l}\text { Criminal } \\
\text { Code Article }\end{array}$ & $\begin{array}{l}\text { Article 364. Abuse of Power or } \\
\text { of Official Status }\end{array}$ & $\begin{array}{l}\text { Article 364-1. Abuse of Official } \\
\text { Authority by an Officer of a } \\
\text { Private Law Legal Entity } \\
\text { Irrespective of Organizational- } \\
\text { Legal Form }\end{array}$ \\
\hline $\begin{array}{c}\text { Crime } \\
\text { Composition }\end{array}$ & $\begin{array}{l}\text { Abuse of power or of official } \\
\text { status, that is, a deliberate, } \\
\text { motivated by lucrative self- } \\
\text { interest, or other personal } \\
\text { interest, or interests of third }\end{array}$ & $\begin{array}{l}\text { Abuse of official authority, that is, } \\
\text { deliberate with the purpose of } \\
\text { gaining illegal benefits for } \\
\text { him/herself or for other persons, use } \\
\text { contrary to the interests of the }\end{array}$ \\
\hline
\end{tabular}

(C) Yatsynina M.-M., 2016 


\begin{tabular}{|c|c|c|}
\hline & $\begin{array}{l}\text { parties, use by an official of } \\
\text { power or of official status } \\
\text { contrary to the interests of } \\
\text { service, where such abuse caused } \\
\text { substantial damage to the } \\
\text { protected by law rights, } \\
\text { freedoms, and interests of } \\
\text { individual citizens, or state or } \\
\text { public interests, or interests of } \\
\text { legal entities }\end{array}$ & $\begin{array}{l}\text { private law legal entity concerned } \\
\text { irrespective of the organizational- } \\
\text { legal form thereof, by an officer of } \\
\text { such legal entity of his/her authority, } \\
\text { where such use caused substantial } \\
\text { damage to the protected by law } \\
\text { rights or interests of individual } \\
\text { citizens, or state or community } \\
\text { interests, or interests of legal entities }\end{array}$ \\
\hline $\mathrm{Sa}$ & $\begin{array}{l}\text { Shall be punishable by corrective } \\
\text { labor for a term of up to two } \\
\text { years, or by imprisonment for a } \\
\text { term of up to six months, or by } \\
\text { restriction of freedom for a term } \\
\text { of up to three years, concurrently } \\
\text { with deprivation of the right to } \\
\text { hold certain positions, or to } \\
\text { engage in certain activities, for a } \\
\text { term of up to three years and } \\
\text { with fine in the amount of two } \\
\text { hundred and fifty to seven } \\
\text { hundred and fifty tax-exempt } \\
\text { minimum incomes of citizens. }\end{array}$ & $\begin{array}{l}\text { Shall be punishable by fine in the } \\
\text { amount of one hundred and fifty to } \\
\text { four hundred tax-exempt minimum } \\
\text { incomes of citizens, or by corrective } \\
\text { labor for a term of up to one year, or } \\
\text { by imprisonment for a term of up to } \\
\text { three months, or by restriction of } \\
\text { freedom for a term of up to two } \\
\text { years, concurrently with deprivation } \\
\text { of the right to hold certain positions } \\
\text { or engage in certain activities for a } \\
\text { term of up to two years. }\end{array}$ \\
\hline $\begin{array}{l}\text { Aggravation- } \\
\text { aggregate } \\
\text { term }\end{array}$ & $\begin{array}{l}\text { Same action where it caused } \\
\text { grave consequences, }\end{array}$ & $\begin{array}{l}\text { Same action, if caused grave } \\
\text { consequences, }\end{array}$ \\
\hline Sanction & $\begin{array}{l}\text { shall be punishable by } \\
\text { imprisonment for a term of } \\
\text { between three and six years } \\
\text { concurrently with deprivation of } \\
\text { the right to hold certain } \\
\text { positions, or to engage in certain } \\
\text { activities, for a term of up to } \\
\text { three years and with fine in the } \\
\text { amount of five hundred to one } \\
\text { thousand tax-exempt minimum } \\
\text { incomes of citizens.. }\end{array}$ & $\begin{array}{l}\text { shall be punishable by fine in the } \\
\text { amount of four hundred to nine } \\
\text { hundred tax-exempt minimum } \\
\text { incomes of citizens, or by detention } \\
\text { for a term of up to six months, or by } \\
\text { imprisonment for a term of three to } \\
\text { six years, concurrently with } \\
\text { deprivation of the right to hold } \\
\text { certain positions or engage in certain } \\
\text { activities for a term of up to three } \\
\text { years. }\end{array}$ \\
\hline
\end{tabular}

As could be inferred, the legislator differentiated responsibility for abuse of office by the criterion of belonging the official to public or private law entity.

But we consider this differentiation inappropriate and unsubstantiated because of a number of reasons such as:

1) Criminal Code of Ukraine was supplemented by art. 364-1 to implement the United Nations Convention against Corruption [2], namely according to Art. 12, each State Party shall take measures, in accordance with the fundamental principles of its domestic law, to prevent corruption involving the private sector, enhance accounting and auditing standards in the private sector and, where appropriate, provide effective, proportionate and dissuasive civil, administrative or criminal penalties for failure to comply with such measures. 
However, to our opinion, with the purpose of fulfilling the Convention it was enough to clarify the rule regarding the criminal liability for official abuse precisely in the private sector, because in the Convention does not provide for different penalties in the public and private sectors in this context, as it is described in Art. 364-1 of the Criminal Code of Ukraine.

2) Such differentiation is inconsistent. For example, in chapter XVII of the Criminal Code Ukraine criminal responsibility is differentiated by criterion of belonging to the officer of a entity of public or private law. However, in Chapter XVII of the Criminal Code of Ukraine only general rules are contained. They provide criminal responsibility for abuse of office. In other chapters of the Criminal Code of Ukraine there are many special rules on them, in which criminal responsibility for such criteria's is not differentiated. For example: in art. 172 Criminal Code of Ukraine «Gross violation of labor law» criminal responsibility for such criteria's is not differentiated. Art. 173 Criminal Code of Ukraine «Gross violation of an employment contract» contain one more non-compliance, because the disposition of this article states: "Any gross violation of an employment contract by any official of an enterprise, institution or organization regardless of their type of ownership...», namely here an enterprise, institution, organization are classified by the form of ownership at that time, when in art. 364 and 364-1 -by the form of creation. In fact, according to p. 2, Art. 81 Civil Code of Ukraine [4], legal entities shall be divided to the legal entities of the Private Law and those of the Public Law. Legal entity of the Private Law shall be organized on the basis of constituent documents according to Article 87 Civil Code of Ukraine. Legal entity of the Public Law shall be established by the regulatory Act of the President of Ukraine, the state power authority and the power authority of the Autonomous Republic of Crimea or the local self-government body.

The same inconsistency is in Art. 175 Criminal Code of Ukraine. Responsibility is not differentiated in all articles containing aggravating circumstances «through abuse of office position», «a person with abuse of office», «officer» and etc.

2) As we know, public relations concerning the correct activities of public authorities, local governments, their staff, enterprises, institutions and organizations irrespectively of ownership forms, persons providing public service are attributed to the generic object of criminal offenses in office.

Yet, as we see it, correct activities of public authorities, local governments, their staff, enterprises, institutions and organizations irrespectively of ownership forms is not an end in itself of Unit XVII of Special part of Criminal code of Ukraine. First of all, human rights and legally protected interests are protected in law-governed state. Thus, committing a service offense, the offender harms not only the right of the enterprise, institution or organization, but the one of a person (citizen), for which the official performs his powers. Human rights must be guaranteed the same regardless of whether that person interacts with the public official or employee of the private sector.

3) Continuing p. 2 it should be noted that in law-governed state, where all the property rights holders shall be equal before the law as provided by Art. 13 of Ukraine's Constitution [1], undertaking of inappropriate activities by public enterprises, institutions and organizations more important than the activities of private enterprises, institutions or organizations is not deemed to be correct.

Establishing lower criminal responsibility for officers of private law than for officers of public law, we are privileging abuses committed by officers of private law, which is unacceptable, because any abuse negatively impacts human rights, freedoms and legally protected interests.

Today, many companies created by administrative act of the President of Ukraine, state authorities, authorities of the Autonomous Republic of Crimea or local government 
are corporatized and act on the basis of statutory documents in accordance with Article 87 of the Civil Code of Ukraine. Therefore, in modern terms the boundaries between enterprises of private and public law are rather blurred.

Also many holdings, corporations and groups etc. consist of various by form of creation entities, and they are working for the one outcome and follow the same principles.

Thus, by its nature, official abuses committed by public law official and abuses committed by private law official, is identical.

In this context, we consider to highlight the most common and necessary signs of abuse committed by officials and persons who provide public services, such as:

1) abuse is committed within the competence.

Powers which are used must necessarily be enshrined in the legal act or individual act as officer powers;

2) abuse is committed with help of special powers.

A person can abuse only those powers, opportunities which are given for realization its activities and which is not her natural rights or opportunities;

3 ) abuse violates the proper activity of such person;

The abuse are actions, contrary to the rules laid down for undertaking of certain activities.

4) to leverage from it for themselves or others is the goal of official abuse.

5) abuse corrupts of public authorities, local governments, their staff, enterprises, institutions and organizations irrespectively of ownership forms.

6) abuse harms person (citizen) rights and legally protected interests.

As we have already noted, correct activities of public authorities, local governments, their staff, enterprises, institutions and organizations irrespectively of ownership forms is not an end in itself of Unit XVII of Special part of Criminal code of Ukraine. First of all, human rights and legally protected interests are protected in law-governed state. Thus, committing a service offense, the offender harms not only the right of the enterprise, institution or organization, but the one of a person (citizen), for which the official performs his powers.

According to the p. a Art. 2 of Convention «Public official» shall mean: (i) any person holding a legislative, executive, administrative or judicial office of a Signatory, whether appointed or elected, whether permanent or temporary, whether paid or unpaid, irrespective of that person's seniority; (ii) any other person who performs a public function, including for a public agency or public enterprise, or provides a public service, as defined in the domestic law of the State Party and as applied in the pertinent area of law of that State Party; (iii) any other person defined as a «public official» in the domestic law of a State Party. However, for the purpose of some specific measures contained in chapter II of this Convention, «public official» may mean any person who performs a public function or provides a public service as defined in the domestic law of the State Party and as applied in the pertinent area of law of that State Party.

To our opinion, Convention emphasizes on the functions performed by the officer. This means that the differentiation of criminal responsibility for official crimes should be made by function performed by the officer. Therefore, abuse of official position by an official of public law and abuse of official position by an official of private law have the same legal nature, character and degree of public danger. Thus, in our opinion, the same criminal responsibility should follow the abuse. Officers, which perform organizational and directing functions or administrative and economic functions and which are not authorized to perform state or local governing functions should be responsible for abuse of office. Sanction for individuals carrying out organizational and directing functions or administrative and economic functions in enterprises, institutions and organizations of state and municipal property, and in private enterprises, institutions and organizations 
must be the same. To our mind, the responsibility for the abuse of power (authority) should be provided by another article of the Criminal code. We consider, such abuse has a higher level and degree of public danger. Subjects of abuse of power (authority) are individuals who in accordance with the Law «On prevention Corruption» are authorized to perform state functions or the duties assigned to local government.

As for the abuse of power by persons who provide public services, we believe that the legislator properly established criminal responsibility for abuse of power by persons who provide public services, and this differentiation is justified, because it concerns other type functions.

From these facts, one may conclude that the responsibility of the officials should be differentiated according to the functions they perform, thus criminal responsibility for abuse of authority, and criminal responsibility for abuse of office irrespectively of ownership forms of enterprise, institution, organization should be established separately.

\section{Список використаної літератури}

1. Конституція України. URL: http://zakon2.rada.gov.ua/laws/show/254\%D0\%BA/96-\%$\mathrm{D} 0 \% \mathrm{~B} 2 \% \mathrm{D} 1 \% 80$

2. Конвенція Організації Об’єднаних Націй проти корупції. URL: http://zakon2.rada.gov.ua/laws/show/995 c16

3. Кримінальний кодекс України. URL: http://zakon5.rada.gov.ua/laws/show/2341-14

4. Цивільний кодекс України. URL: http://zakon2.rada.gov.ua/laws/show/435-15

\section{References}

1. Constitution of Ukraine. Retrieved from http://zakon2.rada.gov.ua/laws/show/254\%D0\%BA/96-\%$\mathrm{D} 0 \% \mathrm{~B} 2 \% \mathrm{D} 1 \% 80$

2. United Nations Convention against Corruption. Retrieved from http://zakon2.rada.gov.ua/laws/show/995_c16

3. Criminal code of Ukraine. Retrieved from http://zakon5.rada.gov.ua/laws/show/2341-14

4. Civil code of Ukraine. Retrieved from http://zakon2.rada.gov.ua/laws/show/435-15

Стаття: надійшла до редакції 03.10.2016 прийнята до друку 20.10.2016

\section{ДИФЕРЕНЦІАЦІ КРИМІНАЛЬНОЇ ВІДПОВІДАЛЬНОСТІ ЗА СЛУЖБОВІ ЗЛОВЖИВАННЯ ЗА КК УКРАЇНИ}

\section{М.-М. Яциніна}

Львівський національний університет імені Івана Франка, вул. Університетська, 1, Львів, Украӥна, 79000, e-mail:martamsy@gmail.com

Досліджено проблеми диференціації кримінальної відповідальності за службові зловживання, критерії дифреренціації кримінальної відповідальності за службові зловживання після внесення змін до КК України у 2011 році законом № 3207-VI від 07.04.2011. Проаналізовано доцільність диференціації кримінальної відповідальності досліджуваної групи злочинів за критеріями, які вибрав українській законодавець. Такий аналіз проведено, враховуючи положення Конвенції Організації Об'єднаних Націй проти корупції та використовуючи метод системного тлумачення кримінального закону. 
Методом узагальнення виділено найзагальніші та необхідні ознаки зловживання, які вчиняють службові особи та особи, що надають публічні послуги.

Зазначено, що за своєю природою зловживання службовим становищем службовою особою публічного права та зловживання повноваженнями службовою особою приватного права мають однакову правову природу, характер та ступінь суспільної небезпеки, тому, на нашу думку, за такі зловживання має бути встановлена однакова кримінальна відповідальність. Особи, які виконують організаційно-розпорядчі або адміністративно-господарські функції і при цьому не є уповноваженими на виконання функцій держави або місцевого самоврядування, повинні нести відповідальність за зловживання повноваженнями, при цьому кримінальна відповідальність (санкція) для осіб, що виконують організаційно-розпорядчі або адміністративно-господарські функції як у підприємствах, установах, організаціях державної та комунальної форми власності та й у підприємствах, установах, організаціях приватної форми власності має бути однакова.

Наголошено, що відповідальність за зловживання владою треба передбачити в іншій статті кримінального закону, оскільки зловживання владою має вищий рівень та ступінь суспільної небезпеки. Суб'єктами такого злочину є особи, які згідно зі ЗУ «Про запобігання» корупції $є$ особами, уповноваженими на виконання функцій держави або місцевого самоврядування. Акцентовано увагу на тому, що законодавець правильно окремо встановив кримінальну відповідальність за зловживання повноваженнями особами, які надають публічні послуги і така диференціація є обґрунтованою, адже ідеться про інший вид функцій.

У результаті дослідження автор підсумовує, що відповідальність службових осіб треба диференціювати за функціями, які вони виконують, відповідно доцільно окремо встановити кримінальну відповідальність за зловживання владою та окремо за зловживання повноваженнями службовою особою незалежно від виду юридичної особи.

Ключові слова: службове зловживання, зловживання владою, зловживання службовим становищем, зловживання повноваженнями. 